\title{
The History, the Memory and the Educational Institution: A Necessary Relationship
}

\author{
Maria Elisabeth Blanck Miguel \\ Pontifical Catholic University of Paraná, Curitiba, Brazil \\ Email: maria.elisabeth@pucpr.br
}

Received 28 April 2016; accepted 26 June 2016; published 29 June 2016

Copyright (C) 2016 by author and Scientific Research Publishing Inc.

This work is licensed under the Creative Commons Attribution International License (CC BY).

http://creativecommons.org/licenses/by/4.0/

(c) (i) Open Access

\section{Abstract}

This paper discusses the relationship between history, memory and the institution of the school. It builds on what the process of searching for, analyzing and interpreting sources according to a theoretical framework reveals about the way the institution of the elementary school came into being in the province of Paraná (1854-1889). Such reflections resulted from dealing with official documents, reports and letters of the public teaching (Presidents of the Province, General Inspectors of Public teaching and teachers who worked in schools) preserved in the Public Archives of Paraná. For in depth analysis we used Le Goff, Saviani, Magalhães, Farge, Bloch, Thompson and Ciavatta. The reflections proceed from the position that teachers demonstrated originated by the schools. It is concluded that although the data presented by the people in charge at the end of the provincial period showed the failure of the school education, in fact, the work of the teachers has contributed to the process of the institution of the elementary school in the Province.

\section{Keywords}

History, Memory, Education

\section{Introduction}

The relationship among the history, the memory and the educational institutions at the beginning comprises two major categories and a subcategory: the history and memory as major categories being the second component of the first and a necessary element of the same. The school institution then arose on the condition of the subcategory since they are part of the history of education and consequently, of the memory.

Among the authors who deal with the relation between history and memory, one has to consider Jacques Le 
Goff. In his work "History and Memory" (1996), the author makes a broad retrospect on how the memory of the human culture development has been historically preserved and quotes Eickelmann (1978) when he affirms “(...) in the Muslim world there remains a kind of memory founded on the memorization of a culture orally and written up at the same time to about 1430; then it changes and reminds of fundamental links between school and memory in all societies” (Eickelmann cited by Le Goff, 1996: pp. 435-436). In the retrospection of history engaged by Le Goff in the mentioned work, the relationship between memory and school is located in the scope of orality and writing. By dealing with the function of memory for the preservation of the Middle Ages culture the author says that (1996, p. 451) "For a long time in the field of literature, the orality continues along with writing and the memory is one of the essential elements of medieval literature". (...) "The educational memory has a similar function." Also recalls that, "In the educational system of the universities after the end of the $12^{\text {th }}$ century, the use of the continuous memory was frequently more based in orality than in writing. Despite the increase in the number of educational manuscripts, the memorization of the teaching courses and oral exercises (disputes, quodlibet $^{1}$, etc.) continues to be the center of the students work” (Le Goff, 1996: p. 452).

On the study of the educational institution in relation to the memory and history, Magalhães says:

The history is the science of memory, which through education in the form of recollecting experience and meaning, updates and substantiates. The historical memory is the collective ownership and individual faculty. Both the spoken and written languages are an extension and source of memory, whose main media are the cartularies, archives, libraries, encyclopedias, files, books. But the monuments, the folklore, the rituals, the uses, the artifacts are signs and representations of collective and individual memories. Remembrance and updating are the two intellectual operations that make it possible to convert the memory into a factor of education. If the monuments, the icons, the artifacts, and lastly the places, the writings and the images are needed for memory, however recollecting (activating) integrates education. Education which in turn, updates the memory. (Magalhães, 2007: p. 181 in Nepomuceno et al.)

The information contained in the sources are used as input to know what was privileged in a particular historical moment, how and why such knowledge was considered relevant, what methods and practices have made part of the pedagogical set of the period taken in consideration, and how their permanence and absences of the set of worked knowledge were justified. But they mainly serve to provide greater and better understanding of the issues and problems of education today. The need for a knowledge of the history of education can be justified by the fact that, if we can understand how education developed, we can then help to improve it. "The substance of history, the educational memory however, does not convert into the subject of history if it remains a heritage. It is under the specific modalities of education that the institutional memories, both collective and individual, and heritage are converted into active and cultural education” (Magalhães, 2007: p. 181, in Nepomuceno et al.).

In an investigation of the history of education we think that there are two possibilities to address in the relationship among history, memory and school institutions: the first is the one that studies school institutions as units; the second studies the historical process of the construction of the school as an institution. In the first case we are dealing with the educational institution as an unit or a specific component of the same group of units. Such units store within themselves similar characteristics in the exercise of similar powers. It includes in this case, for example, the study of a group of school pupils in a given period of time, its organization, its way of operating, students, the formation of the teaching staff and other components that constitute its existence as a particular type of school. It is possible in this focus to understand the meaning of this type of school for the population and the State that they provide from the elements and indicators that will enable the reconstruction of the history of that school. The researches take as an object the other types of educational institutions which are included in this approach.

The investigations that have taken as the object of the research, the specificity of a given educational institution most of the times seek to base themselves theoretically in the approaches derived from the New History, because they prefer the particularities, or fall into the "School culture". This view, as pointed out by Saviani, (2007) brings the concept of school culture to the concept of school practices and allows us to view in the words of the cited author: "Is it possible to say that the school has its own culture, distinct from cultures of other institutions that live with it in the same social formation? What is the degree of autonomy of that 'school culture' in relation to the culture prevailing in the society in which it is inserted?” (Saviani, 2007: p. 8 in Nascimento et al. org, 2007). These questions can be added to paraphrase Nunes, quoted by Ciavatta (2009, p. 42) this type of re${ }^{1}$ In italics, the original. 
search "restricts the institutionalized school activities" and "tends to isolate the education in conditions of real social training to which it belongs". However, it is worth observing that apart from the theoretical choice that it is adopted, the so called New History has the merit of recovering the subject in History. This possibility is important when the researcher goes to the sources and takes his reports, the written word of the professors as his witness, his statement.

The second case, which focuses on the historical process of the school institutionalization and how a determined society built its schools because it felt its need, what is the value that they have given to this social institution, where the changes that it suffered from the social-economical conditions, which is the value that they have given to this social institution, what are the changes that it suffered from the social-economical, political and cultural conditions that have conformed, resulting in a particular focus of an instruction, but in the understanding of the school institution in the process of its construction. This methodology option is based on understanding that the social institutions such as the school are coming from the outcome of the economic and political strain present in the State apparatus and portrays the way the society is at the moment. From this affirmation, we can be in agreement with the thesis of Bourdieu and Passeron, according to which the school institution is one of the ideological apparatus of the State whose purpose would be to, with the transmission of knowledge produced by the bourgeoisie, perpetuate such society.

However, as Saviani has demonstrated, knowledge is not produced by the bourgeoise, but by humanity in its historical development. As such, all the men are their heirs, and for this reason the school should select (namely prepared) and transmit the knowledge that will make it possible for the students and in the possession of it, overcome their own social conditions and participate in the construction of a new society in addition to the capitalist mode of production.

This concept means that all human development parts from the relationship that man establishes with the material world. In order to transform it, it produces knowledge, develops ethical and aesthetic values. Lastly, it produces culture. By transmitting the developed knowledge, the school institution is making the students become partakers of the human society. Studying the historical process of the institutionalization of the school presumes in inserting it in the social relations of production in various contexts, in national and international alliances that shape the lives of people and its institutions (Ciavatta, 2009: p. 42).

It is possible to affirm that the documents, the primary or secondary sources are devices of the memory whose value is only meaningful when interpreted, it reconstructs a part of history.

In the words of Marrou (1956), documents are traits that the past has left us. He says:

We cannot achieve the past, but only through the intelligible traces to us, that these were left behind to the extent that these features remain, where we are able to interpret them. (more than ever, it is important to insist on what happened). Here we find the first and heaviest easements techniques that weigh on the elaboration of history. (Marrou, 1956: p. 68)

It is close to this conceptualization enunciated by Bloch, according to which "what we effectively understand by documents other than a 'trace', that is to say the image, perceptible to the senses, left by a phenomenon in itself is impossible to capture?” (Bloch, 2001: p. 73).

\section{The Memory of the School Institutionalization in the State of Paraná: Archives and Documents}

In our case, we are working with documents produced by agents of the State, or even by their own President of the Province, or then by teachers, investigating how a school was institutionalized in the Provincial period of Parana, what were its limits and advances, which the institutionalization of the school represented the people and the government, which training of the teachers and how they developed their pedagogical practices.

When we read the messages of Presidents we must interpret them as the voice of the State. However, we shall have to consider their political position, their situation in that place and time in history, because it is impossible to interpret what the source communicates to us without considering it inserted in its place and in its moment. In the words of Le Goff “ (...) we can not forget the real places of history of those in which we must search for, not for its elaboration, not for its production, but the creators and the denominators of the collective memory:' States, social media and politicians, communities of historical experiences or of generations carried to constitute their archives as a function of different uses that make memory” (1996, p. 473).

The reports of the teachers portray, even of an indirect way, his training, and in a direct way, the pedagogical 
practices experienced, as well as the perception that the teachers had of the students, the relationship that they developed with them, and even as they related to the parents, with the community, the authorities of the place and the State. Manifestations were also the way they saw their work as well as suggestions that they had to improve this. The reports of the teachers are considered in the study as the teachers statements, testimonials of conditions and real situations that the faculty actually lived, inserted in the social context and particularly, the school.

The written sources, reports and documents, communicate intentions and achievements, but so that the data in memory can be understood it is necessary to know how to inquire them as a result of the objective of the research. Le Goff, in the preface of the work of Bloch “Apologia of History or the task of the historian” (Bloch, 2001: p. 27), says "It is essential to observe that the documents and the witnesses only speak when we know how to interrogate them... 'all historical research implies, since its first steps, that the research has a direction'”. We add that this affirmation should not be taken in an absolute sense because many times the data of the sources modify the first meaning that we wanted to give the research and forces us to focus on new goals and even to replace the problem of the research.

Maria Ciavatta, regarding the research she conducted on historical mediations between work and education, that for the investigations in public archives and libraries have taught her that "neither the school institutions nor the public archives preserve the history of political-pedagogical schools, except scattered fragments". But she discovered that "texts, speeches, correspondence, records of meetings, journals, books, newsletters, photographs, documents of value to the more general understanding of the work and education, and educational policies in the period focused." (Ciavatta, 2009: p. 106). ${ }^{2}$

The research of official documents that indicate the presence or absence of policies of the history of education of Paraná in the period from 1854-1889, under the custody of the Archives of Paraná bring much data that speak of the possibilities or impossibilities (these were, unfortunately in a larger number) by the application of which the State prescribed to be lived and applied in the school's reality. The sources preserved in this Archive brings in contrast to what Ciavatta said, reports, testimonies that depict part of the political-pedagogical schools in the Provincial period of Paraná. However, when the time comes for the search for the Republican period, the sources are dwindling and the search process becomes more difficult.

It is in this perspective that we present this work supported in the research that we have done. We are not affirming that this is the pure and simple result of the studies, but the reflections that the very process of searching for sources, analyze and interpret them according to the theoretical framework that subsidies the research, taught about how the society of Paraná built its school institution and preserved its memory. Also, what we find recorded in the documents shows us how the school space suffered the action of other determinants, such as the culture of the teachers, the action of the families, the mediation of the inspectors. However, in this series, we also discovered, as the students saw the school because they sought, what is the result of the pedagogical practices on their training.

When one wants to know the institutionalization of the school in the state of Paraná one has to go to the archives, that is where the school documents are kept. May they be either public or private; most of the times its memory is part from the same set of sources, the documents, especially the official ones: a set of reports and letters that come from the authorities and the teachers.

The sources from which we want to retrieve the memories of the education in Paraná, (reports and letters) reflect movements that made them on one hand, by the power established in direction of the schools and teachers; but on the other hand, from the central administration. In either direction, such movements were passed by the figure of the general inspector of education and the parish inspector. The first, directly linked to the provincial government, absorbed the information from the parish inspector; who was connected with the schools and the teachers. The relations between the inspectors and the parish inspectors and the teachers almost always were connected with local problems, influences of the authorities of the place, issues about religion, among others. According to Arlette Farge (2009, p. 35), what you can see in the files are elements of reality that by its appearance at a determined time in history, makes sense. It is about this appearance that is necessary to work on and is necessary to decode it. This assertion of the author may be applied to sources such as reports and letters of the public instruction, because they are the ones that keep the memory of education.

In order to illustrate this text we have selected some of the examples of documents from the beginning of the Province (1854), from half of the provincial period (1870) and the years that approached the republic marking ${ }^{2}$ Translated by the author. 
the end of the Province.

The first documents in the year 1854 are letters of teachers that bring the description of the state of the public education, letters from a professor addressed to the President of the Province asking for his resignation from the post because he didn't see any utility in public schools since the students were seeking private schools. However, the Inspector in another letter addressed himself to the President justifying the fact that the students prefer the private school instead of the public. According to the inspector, the mentioned teacher did not attend the classes being away for more than a month dealing with his private matters. The resignation is granted to the requesting teacher.

The other topics of the letters that came from the teachers in the beginning of the Provincial period mentioned its development and also referred to the need for a raise of their salary or their scarcity. In them, the teachers communicated that with what they received they could not maintain the classroom in which they taught (in which most of the time were their own houses); they requested repairs of the windows, school materials, in addition to saying the poor situation of the students. The local authorities have asked the President of the Province to create classes of Latin and French, in which one could see the possibility of contributing to the progress of the Homeland. These demands are opposed to the demands for first graders in which students can be literate.

Teachers' reports show how they see their own work and also give their suggestions to improve such work. As these are topics that are found in all reports from the teachers, they are considered true, because " $(\ldots)$ it is necessary to surrender to the evidence that numerous witnesses agree on this or that gesture. (...)" (Farge, 2009: p. 44). And also, "(...) what is seen in these very rare words are elements from reality which by its appearance in a particular historical moment make sense.” (Farge, 2009: p. 36).

Teacher Francisco Antunes Teixeira, from Paranaguá, on July $28^{\text {th }}$, 1854, in his report to the President of the Province, Counsellor Zacarias de Góes and Vasconcellos, wrote:

It seems incredible that one can accommodate on seven benches (that is the number in the classroom) of 8 inches each 70 students, which is the number of students that are enrolled. However it is necessary to accommodate them, even in such a small area, the area of where the students touch each other! There is only one bench in the classroom where the boys write, but a relatively small one which can have 18 boys at most, nine on one side and nine on the other. (...) Finally I conclude informing your Excellency that it is quite remarkable the number of poor boys that attend public school who are not given any papers and pens. I have given those materials to them on my own expenses (the ones from my class). Without those, they wouldn't be able to learn. (Teixeira, 1854: p. 35)

The General Inspector of Public Instruction Ernesto Francisco de Lima Santos, on January 24, 1870, in the report to Dr. Antonio Luiz Affonso de Carvalho, President of the Province, described the social and economical situation of the population:

In a province like this where the population in a large part lies disseminated, far from the villages in which the father of the family is the salutary means of properly educating their children, the coercion of the matter of teaching is a disease. How can a poor farmer that lives far from villages send his child to be taught the rudiments of education? Sending his child to school through long distances when one doesn't even have the means to do so or neither owns a decent house where his child can live while attending school. (Santos, 1870: p. 25)

The perception of education portrayed by the then President Luiz Affonso de Carvalho has not differed in much of what was manifested by the Inspector quoted above. Said the Provincial President in the report to the Legislative Assembly of Paraná, February 15, 1870:

Here in Paraná much has been written about the public schools: long essays are found in the official documents, which certify the high illustration of the authors and of the good desires that they had. However, it is necessary that we do not dissemble it: if much has been written, advising the legislature, little has been practiced and obtained and unfortunately in the field of public service, more than in all other services, the time that has been wasted cannot be recovered. The proof is in the classification of the schools, in its movement of frequency, in the number of students annually prepared and the qualifications of the teachers with some exceptions; meanwhile being the primary education the source of all human knowledge, if in the administration distinction should be made, I believe it should be given the fullest attention. The principle of gratuitousness established in the constitution brings to an end the liberal thoughts of removing from the 
classes in need their greatest obstacle to their instruction and impose the provincial assemblies, whose office was the primary instruction, duties of the highest responsibility in the present and in the future, who should meet these conditions may not exempt one of the missing essential parts in your mission. How to respond to such a high burden? We can say that the need for the practical activity of teaching is more important than the reforms, which swells the legislation and become ignored. We have two kinds of classes, the definite and the contracted. Of the first type there are 32 divided in 18 for male sex and 16 for female sex. The second type has 14 divided in 11 for boys and 3 for girls. During last year these classes were attended by 1690 students, 957 male students were definite and 439 female students were contracted, out of these 245 were male and 49 were female. Out of these students only 71 finished the studies and were considered ready; 52 were boys and 19 were girls. A similar result cannot be satisfied neither for the proportion of the frequency of 1690 students nor for the number of 46 schools, with this result less than 2 students per school passed. Either there wasn't enough care on the teachers part, the teachers weren't skilled enough, there was a great number of absences of the students, or this number is an illusion. The number of students prepared last year was still lower than in 1868, which had only 5 more students. These numbers are eloquent and they demonstrate themselves the futility of any further comment. (Carvalho, 1870: p. 10)

On August 4, 1880, Manoel Pinto de Souza Dantas Filho, having turned the administration over to João José Pedrosa, communicates that there was a shortage of students in the vicinity of Curitiba. In the same report a donation of money for the construction of a female and male school was made granted by The Emperor Sir Pedro II when he visited the Province.

He also reported that:

(...) on June 22 he notified to the ministry of agriculture, commerce and public works of the Royal Court to proceed in the construction of schools inspected by the general inspector of the province, and which they could go from 8 - 10 (contos de réis) along he also requested that the inspector present a drawing of the proper furniture and utensils for these schools. Once sent to the presidency such budgets and drawings must be sent to the commission so that the works can be observed. So this commission waits for an opportunity to begin this task that they are responsible for and suggest the idea of opening a savings account to put away these imperial donations and others to this presidency that may be donated from the private hand-outs to be increased as it has to be done. (Dantas Filho, 1880: p. 12)

The committees were composed of representatives of Antonina, Ponta Grossa, Morretes, Castro, Palmeira and Lapa, in addition to the president himself. "To the first of these localities. S. M. the Emperor donated 500.000 contos de réis; to the second 500.000, to the third the donation of 300.000, to the forth 500.000 and to the fifth 500.000” (Reported, 1880).

In the period prior to 1870 in the official documents consulted, there were discussions about the urgency of the creation of "teachers preparatory school" to train teachers and still it was an apologetic discourse on the need for the instruction of the female sex. This would not only be a sacred debt by the State for this important part of the society", but, "one of the safest and most efficient ways of wide spreading the need of the primary schooling and the real progress” (Report, Manoel Pinto Dantas Filho, 1880). The "Teachers Preparatory School was created by the law number 238 on April 19, 1870, signed by President Antonio Luiz Affonso de Carvalho. For women, the curriculum had undergone modifications to accommodate the teaching” (Miguel, 2008: p. 148 in Araujo et al, 2008). This institution was designed to prepare teachers of both genders who wanted to pursue a pedagogical elementary school. However, the school opened and closed several times to assert itself as a center for the preparation of the magisterium in the 20 's, the $20^{\text {th }}$ century.

The majority of the reports has exposed manifest to the voice of the State. They represented the position of the government, almost always expressing the liberal thought based on the real conditions in which the Province was, which means that the production depended on the land rent for wintering of the troops who went to Viamão (RS) and to Sorocaba (SP) by the production of tea, that was the harvesting process and trade of the mate tea. Although a stream of Historians from Paraná assert that this process is now treating one type of industrialization, the Brazilian production system depended on slave labor until 1888. Ruy Wachowicz (2010) affirms that

In the beginning of the product industrialization, the labor force used was predominantly slave. Later, with the arrival of a massive immigration and the growing complexity of the industrialization there was a demand for literate individuals. In this way, the free labor ended up replacing the slaves in the branch of production. (Wachowicz, 2010: p. 156) 
The reading and analysis of the reports presented here are enabling us to raise the categories of: precariousness of school, the teachers materials, and lack of teacher formation, confrontation of ideas on education between the government and the people. It is worth recovering what Ciavatta (2009) says while working with photographs to research the historical mediations between work and education. The author considers that her sources, in case of the photographs will be converted into mediation when they are studied as expressions of consequences from the appreciation of the work to the detriment of the worker, making possible the construction of analysis categories. In the case of our research reports and letters as devices of some of the history of education from Paraná, they are transformed into mediation to be analyzed as expressions of the social economical, political and cultural context and enabling the removal of categories of analysis on education of the Provincial from Paraná. In the reports registered by the teachers we find the real conditions in which the education of the Province was immersed, and have identified in 1870, some progress in relation to the methods to be employed in the schools. On December 8, 1870, the teacher from Paranaguá called Maria Bernarda Pinto Cordeiro informed in a report to the superior authority (without records) the conditions of her students' classroom, furniture, utensils and methods. She said the following:

There are currently 47 students enrolled who regularly attend the school, to which I have divided into three classes as follows: in the first there are 22 students and in the second there are 20 and in the third there are 5 students. Almost all are endowed with a good character, and are applied to their studies. I rely my most flattering hopes on their intellectual development. It is to be regretted that for the most part of them, daughters of poor and ignorant men who have no resources, when these girls have just begun how to read and write, they are judged as if they have already learned everything so they are taken from the school without ever finishing the true principals; using their growth and the sacrifice that they are doing, not only to keep them decently dressed, as also with books and paper as an excuse to some. This is the reason that I beg for their sake to the Provincial Government, so that these parents can encourage them and maybe even have a bigger desire and this might grow on them that their daughters will learn so that all this sacrifice will not have been in vain. (Cordeiro, 1870: p. 125)

As to the method, she reported that:

I have been using the pure simultaneous method because they consider it better, and much more is grasped since I have been teaching and explaining without the help of an aid or monitor. I have employed this method, aided by analytical-explanatory. This offers great advantages because without boring the children by having them memorize long lessons you feel that they understand what I have been teaching them. (Cordeiro, 1870: p. 126)

Relating to where the school is functioning:

I have had to help pay the rent with part of my small salary even though the school is almost downtown and it neither has the appropriate accommodations, it is impossible to find a house to rent in conditions required by the regulations or find one for what the government offers. (Cordeiro, 1870: p. 126)

Regarding to the furniture:

Every day the school suffers from the lack of essential materials such as pen and paper and benches which have no backs, requiring that the children sit in a very uncomfortable position, even harming their posture. These ailments could be avoided if the repairs or reforming had been done on them. (Cordeiro, 1870: p. 126)

Taking this report a parameter of the speeches by the teachers, in 1870 the conditions of existence of the public school in Paraná continued without any support from the government in the Provincial period as well as the classroom and the teachers expenses and the school material. What seems to appear again is the modification of the simultaneous method assisted by a teacher entitled as analytical-explanatory. Still the poverty of the population did not allow the children to be offered better conditions of life which hasn't made their stay in school any easier. The teacher Pedro Saturnino de Oliveira Mascarenhas also reported on December 1, 1884 about the municipality of Castro to the General Director of Public Instruction, João Manoel da Cunha, about the situation of the classroom, the furniture and the materials.

My classroom continues to operate in the house of the citizen José Soares Maciel since we have not been able 
to obtain another in better conditions. It is fairly sparse, but sufficient for the number of students that attend school.

(...) The furniture of the school is the same as when your Excellency Mr. Dr. President Dantas found them in 1880. It was not possible to make other furniture of have them repaired. As to the lack of books and some more objects that the school needs to supply the poor boys, it is unfortunate that there is an urgent need for this acquisition; because there have been many times where the boys were no longer attending classes, fearing the rebuke of their teachers. I have bought and distributed several times those materials on my own expense to some poor boys so that they would not miss school, for this reason I ask you to kindly suggest to your Excellency Mr. Dr. President a small fund of 100.000 - 200.000, (contos de réis) so that we can make some improvement in the school and buy some books for the poor children. (Mascarenhas, 1884: p. 176)

At the gates of the Republic, the report of the president of the Province, Dr. Joaquim de Almeida Faria Sobrinho presented a Legislative Assembly on February 17, 1887, he did not show satisfaction with the situation of the public education expressed both in the words of the President as well as in quantitative data. The ruler expressed:

The needs of the Public Schooling of the Province are well known. As I have had the opportunity to say in my report on October first of last year, I urge for this radical reform. It is not flattering to see the situation it is in, the efforts made are not matched by the results obtained, very little attention to the population and the number of schools that has been provided. (Faria Sobrinho, 1887: p. 75)

These words were reflected in the data:

Representing a number of children and adults which enrolled and attended the 123 public school, the 58 subsidized schools and the 4 municipal (evening classes), the 120 private schools and the 3 regulatory, the sum below declared:

$\begin{array}{lcc} & \text { Enrolled } & \text { Attending } \\ \text { Male students } & 4.370 & 3.416 \\ \text { Female students } & \underline{2.109} & \underline{1.754} \\ & 6.479 & 5.170\end{array}$

Of these numbers there were 68 male students and 84 female students approved in their final examinations, according to reports received. (Faria Sobrinho, 1887: p. 77)

When at the beginning of the text we refer to the value of the redemption of the character in the story we read the reports of the Public schools in the Provincial period, we find the continuous manifests about the reality of their students, the difficulties they had in the learning process that has been exacerbated by the poor conditions in which the school functioned. As well as the poor working conditions of the teachers, the issues of the provision of the schools that were often created, but were not provided, the lack of school material, the distances between the places where they lived and the location of the schools, the non-valuation of the school by the parents were situations to which the teachers were attentive and insistently reporting.

\section{Conclusions}

Although the data presented in the report above suggests that the school at the end of the Provincial Period did not work, at least not satisfactorily, the process of its institutionalization had begun and in the first decade of the $20^{\text {th }}$ century, when thanks to the progress of the coffee crop, the process of urbanization and the implementation of the policies of migration and immigration directed and enabled the village of the State of Paraná, the institution of the school became a reality. Although the conditions did not facilitate the institutionalization of elementary school, the teachers who were involved in the task of the magisterium were launching their functions, but limited by their own terms and conditions that the ways imposed on them.

Bloch (2001) says that it is necessary to collect testimony of those who were involved in facts that were researched. In the case of our research, we consider that the reports and letters from the teachers in which they denounce the poor conditions in which they and their students work are statements that are left in the memories preserved by the documents. When we value the testimonies of the teachers, we do so because we believe that they speak about their experiences of life with the students, about their practices which led them to make sug- 
gestions to the government. They created, they can affirm, a social conscience which came from the relationship that they had established with their students and with themselves, and the objective reality of the sense that Thompson (2009) gives to experience. This experience is not always formed in the Teacher Preparatory School but the experiences gave them knowledge of the reality and the most urgent need that they had and that their students also presented. Thompson in discussion with Althusser, values the experience and says "(...) knowledge has been formed and still is formed out of the academic procedure. It has helped men and women to work the areas, to build houses, to maintain complicated social organizations, and even occasionally to effectively question the conclusions of academic thinking” (Thompson, 2009: p. 16).

However, whilenot wishing to minimize the importance of teacher training courses, wewould like to emphasize that for these teachers, given the conditions under which they taught, experience was very important and in most cases was a substitute for vocational training. However, we know that the institutionalization of elementary school in the Province was a product of the conditions of the material production that existed in that moment in history. However, in the interior of the state, people who had not always been trained as teachers but who were working in this capacity and performing duties of the State gained experiencefrom their work and accordingly drew conclusions that they judged correct for improving public education and student's lives.

When we go to the archives, we do this because we know that in the sources they preserve and keep the memory or fragments of memory of what we want to investigate. Thus, to examine the reports and letters of public schooling in the provincial period we believe that reconstructing as far as possible, the history of this institution is able to contribute to the history of education in the State of Paraná. Also the singularities found in the investigations of the history of the regional education allow one to understand the national context and help to develop a new synthesis of the history of the national education.

\section{References}

Bloch, M. (2001). Apology of History of the Art of a Historian. Rio de Janeiro: Jorge Zahar Editor.

Carvalho, A. L. A. de (1870). A Report Presented to the Legislative Assembly of Paraná to the President of the Province Antônio Luiz Affonso de Carvalho, on February 15. In Public Archives of Paraná (pp. 9-15). Report, Curitiba, 353.0313. http://www.arquivopublico.pr.gov.br/arquivos/File/RelatoriosGoverno/Relatorio_1870_Presidente_MFN_668.pdf

Ciavatta, M. (2009). Intervention of Labor: Education, Genesis and the Dispute of the Schooling of the Workers. (Rio de Janeiro, 1930-1960). Rio de Janeiro: Lamparina, CNPq, Faperj.

Cordeiro, M. B. P. (1870). A Report from the Teacher Maria Bernarda Pinto Cordeiro from Paranaguá, Sent to the Inspector of the Public Instruction, on December 8. In: Public Archives of Paraná (pp. 125-126). Report, Curitiba, V. 22 , N 345. Unpublished Document.

Dantas Filho, M. P. de S. (1880). A Report from Manoel Pinto de Sousa Dantas Filho the João José Pedrosa on the Transmission of the Administration of the Province, on August 4. In Public Archives of Paraná (pp. 11-13). Report, Curitiba, 353.0313. http://www.arquivopublico.pr.gov.br/arquivos/File/RelatoriosGoverno/Ano1880MFN675.pdf

Farge, A. (2009). The Flavor of Archives. Translated Fátima Murad. São Paulo: Edit. USP.

Faria Sobrinho, J. de A. (1887). Report Presented to the Legislative Assembly by the President of the Province, on February 17. In Public Archives of Paraná (p. 223). Report, Curitiba, 353.0313.

http://www.arquivopublico.pr.gov.br/arquivos/File/pdf/rel_1887_p.pdf

Le Goff, J. (1996). History and Memory. Translation: Bernardo Leitão et al. Campinas, S. P: Ed. UNICAMP.

Magalhães, J. (2007). History and Memory. Museum Archives: Challenges of Educational Training and the Historical Investigation. In M. A. Nepomuceno, \& E. F. A. Tiballi (Eds.). Education and Its Individuals in School (pp. 181-189). Belo Horizonte: Argumentum.

Marrou, H. I. (1956). Of Historical Knowledge. Paris: Éditions du Seuil.

Mascarenhas, P. S. (1884). A Report to the lifetime Pedro Saturnino de Oliveira Mascarenhas sent to the Director General of the Public Instruction of the Province of Paraná on December 1. In: M. E. B. Miguel, (Ed.). Reports and Letters of Public Instruction of Provincial Paraná (1870-1889) (p. 176). Collection Documents of Brazilian Educacion. Vol. II, Virtual Books: SBHE. http://virtuallivros.com.br/modules/catalogo/public-photo.php?photoId=10

Miguel, M. E. B. (2008). Normal School of Paraná: Institute of the formation of Teachers and the Educator of the People. In: J. C. S. Araujo et al. (Eds.). The Normal Schools of the Empire of the Republic of Brazil (pp. 145-162). Campinas, S. P: Alínea.

Santos, Ernesto Francisco de Lima (1870). A Report from the Inspector General of the Public Instruction Santos on January $24^{\text {th }}, 1870$ to the President of the Province Antônio Luiz Affonso de Carvalho. In: M. E. B. Miguel (Ed.). Reports and 
Letters of Public Instruction of Provincial Paraná (1870-1889) (pp. 234-278). Collection Documents of Brazilian Educacion. Vol. II, Virtual Books: SBHE.

http://virtuallivros.com.br/modules/catalogo/public-photo.php?photoId=10

Saviani, D. (2007). School Institutions in Brazil: The Concept and the Historical Reconstruction. In: , M. I. M. Nascimento et al. (Eds.) School Institutions in Brazil - The Concept and the Historical Reconstruction (pp. 3-27). Campinas: Edit. Associated Authors.

Teixeira, F. A. (1854). A Report from Professor Francisco Antunes Teixeira, from Paranaguá, on July $28^{\text {th }}, 1854$ to The President of the Province, Counselor Zacarias de Góes e Vasconcellos. In: M. E. B. Miguel, (Ed.). Reports and Letters of Public Instruction of Provincial Paraná (1870-1889) (pp. 56-57). Collection Documents of Brazilian Educacion. Vol. I, Virtual Books: SBHE. http://virtuallivros.com.br/modules/catalogo/public-photo.php?photoId=9

Thompson, E. P. (2009). The Theory of Misery or a Planetary of Errors. Translator Waltensir Dutra. Rio de Janeiro: Zahar Editor.

Wachowicz, R. C. (2010). The History of Paraná (10th ed.). Ponta Grossa/PR: Edit. UEPG. 